\title{
Attitude and Knowledge of Undergraduate Students of South Coastal Karnataka and Kerala Region towards Various Specialisations in Dentistry- A Cross Sectional Study
}

\author{
Anupama Prasad D. ${ }^{1}$, Swathy Jayasoman², Krishna Prasad D. ${ }^{3}$ \\ ${ }^{1}$ Department of Prosthodontics, ABSMIDS, NITTE (Deemed to be University), Mangaluru, Karnataka, India. \\ 2Department of Prosthodontics, ABSMIDS, NITTE (Deemed to be University), Mangaluru, Karnataka, India. \\ ${ }^{3}$ Department of Prosthodontics, ABSMIDS, NITTE (Deemed to be University), Mangaluru, Karnataka, India.
}

ABSTRACT

\section{BACKGROUND}

Dentistry is a skill-based profession. Various specialisations are found in this field and several short-term certificate courses are also taking birth to cater to the need of newly graduated student population who want to set up practices afresh. We wanted to assess the attitude and knowledge of undergraduate dental students towards various specialisations.

\section{METHODS}

A cross-sectional survey of all final year dental undergraduates and house surgeons was carried out by distributing semi-structured questionnaire to 212 undergraduate dental students from various colleges in South Coastal Karnataka and Kerala region. Statistical analyses were carried out using chi- $^{-}$square test and Fisher's exact test.

\section{RESULTS}

The study found that $89.6 \%(n=190)$ respondents desired to pursue a specialisation. $91 \%(n=111)$ of the total final year students and $87.8 \%(n=79)$ of total interns desired to specialise. Majority of them were females $76.9 \%(n=163)$. Oral surgery was the first choice of specialisation amongst final years and conservative \& endodontics among interns. Least preferred was oral pathology.

\section{CONCLUSIONS}

Attitude and knowledge of students varied widely with respect to gender, year of study, and external influencing factors. Females were more inclined to specialisation despite the obstacles they would face.

\section{KEY WORDS}

Specialisation, Dentistry, Attitude, Cross-Sectional Survey, Knowledge
Corresponding Author: Dr. Krishna Prasad D., ABSMIDS, NITTE, (Deemed to be University), Deralakatte-575018, Mangaluru, D.K District, Karnataka, India. E-mail: drkrishnaprasadd@nitte.edu.in

DOI: $10.14260 / j e m d s / 2020 / 441$

How to Cite This Article:

Prasad DA, Jayasoman S, Prasad DK. Attitude and knowledge of undergraduate students of south coastal Karnataka and Kerala region towards various specialisations in dentistry- a cross sectional study. J. Evolution Med. Dent. Sci. 2020;9(29):2023-2027, $10.14260 / \mathrm{jemds} / 2020 / 441$

Submission 29-01-2020, Peer Review 13-06-2020, Acceptance 19-06-2020, Published 20-07-2020.

Copyright (C) 2020 JEMDS. This is an open access article distributed under Creative Commons Attribution License [Attribution 4.0 International (CC BY 4.0)] 


\section{BACKGROUND}

Dentistry is an emerging career option in India. Undergraduation alone is not enough to hone the technical skills and expertise of students. With the advent of technology and internet-based knowledge, the aesthetic and functional needs of patients have increased. People are aware of the different treatment options available. Awareness of consulting a specialist is more and patients seldom go to a general practitioner. Pursuing a speciality has become more necessary than ever. This calls for the students need to specialise.

Compared to intake of undergraduate seats, post graduate intake is less ${ }^{1}$. So, the opportunity narrows. Hence students must opt for lateral short-term courses to improve technical skills. There are eight specialisations to choose from namely clinical subjects like Prosthodontics, Endodontics, Oral and Maxillofacial Surgery, Periodontics, Pedodontics, Orthodontics along with non - clinical subjects like Oral Pathology \& microbiology and Oral Medicine \& Radiology. A variety of certificate courses like Implantology, Treatment of temporomandibular disorders, Aesthetics, Dental Photography, Smile designing etc. are also available. In India, there are centralised exams conducted for post-graduation and entries into these are based purely on merit. Pursuing post-graduation depends on a multitude of factors. Along with their personal interest, their family background and economic status plays a pivotal role. Since students are partially dependent on their parents to financing their post-graduation, their financial liabilities should be considered as an important factor.

The choice of a medical or a dental career is motivated beyond doubt by the financial and social status of those professions. ${ }^{2}$. While some dental students are primarily driven by a desire for status, prestige, varied work, and the opportunity to put theory into practice, benevolent intentions regarding helping people and improving their appearance serve as incentive for others. Regardless of their reason for choosing dentistry as a career, the expectation of a secure and bright professional future is what keeps most students motivated during their dental education ${ }^{3}$. It is important to understand students' motives for choosing dentistry and their views concerning the future of their profession to preserve a motivated workforce. ${ }^{4,5}$ Possessing skills in the field is also a reason to opt for specialisation. ${ }^{6}$ Money, self-interest and encouragement were reasons of students from Japan and Sweden to opt for specialisation. ${ }^{7}$ Social standing and status were motivational factors for students from Chennai. ${ }^{8}$ The most dominant motivational factors for students from Canada, were the desire for a financially lucrative profession and job security, followed by a desire to work with or help people. ${ }^{9}$ In Wales students said they chose dentistry because of the opportunity to utilize their manual and technical skills, followed by the opportunity to help people and be selfemployed and independent. In Scandinavian countries factors motivating students to choose dentistry as a career were a desire for varied work, the opportunity to put theory into practice, and altruism. ${ }^{10}$ In a study in Iran a significant relationship was found between students' interest in dentistry and their personal attitudes about the future of the profession. ${ }^{11}$
In India very few studies have been conducted to understand the attitude and knowledge about undergraduates in which they indicate a wish to specialise or opt for general practice, the reasons for their choices, and their reported preparedness for future speciality training.

\section{Aim}

Aim of this study was to assess the attitude and knowledge of undergraduate students towards various specialisations, in dental colleges in South Coastal Karnataka and Kerala region.

\section{Objectives}

- $\quad$ To assess the attitude of undergraduate students towards pursuing specialisation.

- To determine the factors affecting choice of specialisation.

- To assess the factors influencing the choice between pursuing specialisation or certificate courses.

\section{METHODS}

A sample of 212 undergraduate students of both genders who were willing to participate in the study from South Coastal Karnataka and Kerala were included. The sample size was determined using the formula $\mathrm{Z}_{1-\mathrm{a} / 2} \mathrm{p}(1-\mathrm{p}) / \mathrm{d}^{2}$ where $\mathrm{Z}_{1-\mathrm{a} / 2}$ is the normal standard variate, $\mathrm{p}$ is the expected proportion in population based on previous studies and $d$ is the absolute error or precision. The study was a cross-sectional questionnaire with convenience sampling method conducted within a period of 6 months duration. A self -compiled questionnaire relevant to the present study was prepared and subjected to face validity. Each participant was given the questionnaire and the investigator assured completeness of the record. A single investigator was responsible for collecting the report to avoid bias. Informed consent was obtained from each subject and anonymity of responses was assured to the participants.

\section{Statistical Methods}

Data collected were analysed using IBM SPSS Statistics, Version 24 (Armonk, NY: IBM Corp). Descriptive data were presented in the form of frequency and percentages. Comparisons of the categorical variables between the gender and category groups were performed using the Chi Square test and Fishers test. P value $<0.05$ was considered as statistically significant.

\section{RESULTS}

\begin{tabular}{|c|c|c|c|c|c|}
\hline \multirow{2}{*}{ Response } & \multicolumn{2}{|c|}{ Category } & \multirow{2}{*}{ Total } & \multicolumn{2}{|c|}{ Chi Square Test } \\
\hline & Final Year & Intern & & Chi Square Value & P-value \\
\hline \multirow{2}{*}{ Yes } & 111 & 79 & 190 & \multirow{3}{*}{ Git squar varue } & \multirow{3}{*}{$0.45(\mathrm{NS})$} \\
\hline & $91.0 \%$ & $87.8 \%$ & $89.6 \%$ & & \\
\hline No & 11 & 11 & 22 & & \\
\hline \multicolumn{6}{|c|}{$\begin{array}{l}\text { Table 1. Comparison of Percentage of Willingness to Pursue } \\
\text { Specialization between Final Year Students and Interns }\end{array}$} \\
\hline$<0.05 \mathrm{Sta}$ & ically Signific & $\mathrm{t} p>0.0$ & Si & Nont & \\
\hline
\end{tabular}




\begin{tabular}{|c|c|c|c|c|c|}
\hline \multirow{2}{*}{ Response } & \multicolumn{2}{|c|}{ Category } & \multirow{2}{*}{ Total } & \multicolumn{2}{|c|}{ Chi Square Test } \\
\hline & Final Year & Intern & & Chi Square Value & P-Value \\
\hline Yes & 88 & 57 & 145 & \multirow{3}{*}{1.86} & \multirow{3}{*}{0.17 (NS) } \\
\hline & $72.1 \%$ & $63.3 \%$ & $68.4 \%$ & & \\
\hline No & $\begin{array}{c}34 \\
27.9 \%\end{array}$ & $\begin{array}{c}33 \\
36.7 \%\end{array}$ & $\begin{array}{c}67 \\
31.6 \%\end{array}$ & & \\
\hline \multicolumn{6}{|c|}{$\begin{array}{l}\text { Table 2. Comparison of Speciality Exposure in } \\
\text { Their Respective Colleges between Categories }\end{array}$} \\
\hline${ }^{*} \mathrm{p}<0.05 \mathrm{St} z$ & tically Signifi & $\mathrm{t}, \mathrm{p}>0.0$ & n-Sig & cant, NS & \\
\hline
\end{tabular}

\begin{tabular}{|c|c|c|c|c|c|c|}
\hline & & \multicolumn{2}{|c|}{ Category } & \multirow[b]{2}{*}{ 즁 } & \multicolumn{2}{|c|}{$\begin{array}{c}\text { Chi-Square } \\
\text { Test }\end{array}$} \\
\hline & & 施 & $\stackrel{\Xi}{\Xi}$ & & 完 㫯 & 音 \\
\hline \multirow{3}{*}{$\begin{array}{c}\text { Choice of } \\
\text { Specialization }\end{array}$} & Clinical & $\begin{array}{c}117 \\
95.9 \%\end{array}$ & $\begin{array}{c}82 \\
91.1 \%\end{array}$ & $\begin{array}{c}199 \\
93.9 \%\end{array}$ & \multirow{3}{*}{2.07} & \multirow{3}{*}{ 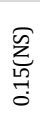 } \\
\hline & \multirow{2}{*}{ Non-clinical } & 5 & 8 & 13 & & \\
\hline & & $4.1 \%$ & $8.9 \%$ & $6.1 \%$ & & \\
\hline \multirow{8}{*}{$\begin{array}{l}\text { First Choice of } \\
\text { clinical subject } \\
\text { for } \\
\text { specialization }\end{array}$} & Oral surgery & $\begin{array}{c}37 \\
30.3 \%\end{array}$ & $\begin{array}{c}17 \\
18.9 \%\end{array}$ & $\begin{array}{c}54 \\
25.5 \%\end{array}$ & \multirow{8}{*}{8.46} & \multirow{8}{*}{$\sum_{\substack{n \\
0}}^{\pi}$} \\
\hline & Orthodontics & $\begin{array}{c}29 \\
23.8 \%\end{array}$ & $\begin{array}{c}22 \\
24.4 \%\end{array}$ & $\begin{array}{c}51 \\
24.1 \%\end{array}$ & & \\
\hline & Fndodontics & 31 & 32 & 63 & & \\
\hline & Enaouontucs & $25.4 \%$ & $35.6 \%$ & $29.7 \%$ & & \\
\hline & Prosthodontics & $\begin{array}{c}11 \\
9.0 \%\end{array}$ & $\begin{array}{c}3 \\
3.3 \%\end{array}$ & $\begin{array}{c}14 \\
6.6 \%\end{array}$ & & \\
\hline & Periodontics & $\begin{array}{c}5 \\
4.1 \%\end{array}$ & $\begin{array}{c}6 \\
6.7 \%\end{array}$ & $\begin{array}{c}11 \\
5.2 \%\end{array}$ & & \\
\hline & Pedodontics & 9 & 10 & 19 & & \\
\hline & Pedodontics & $7.4 \%$ & $11.1 \%$ & $9.0 \%$ & & \\
\hline \multirow{5}{*}{$\begin{array}{l}\text { Second Choice } \\
\text { of clinical } \\
\text { subject for } \\
\text { specialisation }\end{array}$} & Oral surgery & $\begin{array}{c}28 \\
23.0 \%\end{array}$ & $\begin{array}{c}13 \\
14.4 \%\end{array}$ & $\begin{array}{c}41 \\
19.3 \%\end{array}$ & \multirow{5}{*}{3.05} & \multirow{5}{*}{ 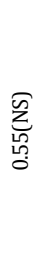 } \\
\hline & Orthodontics & $\begin{array}{c}35 \\
28.7 \%\end{array}$ & $\begin{array}{c}28 \\
31.1 \%\end{array}$ & $\begin{array}{c}63 \\
29.7 \%\end{array}$ & & \\
\hline & Endodontics & $\begin{array}{c}23 \\
18.9 \%\end{array}$ & $\begin{array}{c}16 \\
17.8 \%\end{array}$ & $\begin{array}{c}39 \\
18.4 \%\end{array}$ & & \\
\hline & Prosthodontics & $\begin{array}{c}17 \\
13.9 \%\end{array}$ & $\begin{array}{c}14 \\
15.6 \%\end{array}$ & $\begin{array}{c}31 \\
14.6 \%\end{array}$ & & \\
\hline & Periodontics & $\begin{array}{c}19 \\
15.6 \%\end{array}$ & $\begin{array}{c}19 \\
21.1 \%\end{array}$ & $\begin{array}{c}38 \\
17.9 \%\end{array}$ & & \\
\hline \multirow{4}{*}{$\begin{array}{l}\text { first choice of } \\
\text { non-clinical } \\
\text { subjects for } \\
\text { specialisation }\end{array}$} & Oral pathology & $\begin{array}{c}22 \\
18.0 \%\end{array}$ & $\begin{array}{c}8 \\
8.9 \%\end{array}$ & $\begin{array}{c}30 \\
14.2 \%\end{array}$ & \multirow{4}{*}{12.05} & \multirow{4}{*}{ 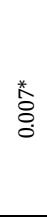 } \\
\hline & Oral radiology & $\begin{array}{c}62 \\
50.8 \%\end{array}$ & $\begin{array}{c}34 \\
37.8 \%\end{array}$ & $\begin{array}{c}96 \\
45.3 \%\end{array}$ & & \\
\hline & Phd/research & $\begin{array}{c}17 \\
13.9 \%\end{array}$ & $\begin{array}{c}26 \\
28.9 \%\end{array}$ & $\begin{array}{c}43 \\
20.3 \%\end{array}$ & & \\
\hline & Not applicable & $\begin{array}{c}21 \\
17.2 \%\end{array}$ & $\begin{array}{c}22 \\
24.4 \%\end{array}$ & $\begin{array}{c}43 \\
20.3 \%\end{array}$ & & \\
\hline \multicolumn{7}{|c|}{ Table 3. Preferred Branches for Specialisation between Categories } \\
\hline \multicolumn{7}{|c|}{${ }^{*} \mathrm{p}<0.05$ Statistically Significant, $\mathrm{p}>0.05$ Non-Significant, NS } \\
\hline
\end{tabular}

\section{Demographics}

Questionnaires were answered by $(n=212)$ respondents. Out of which majority were in the age group of 21-22 years. Categorically (57.5\%) respondents belonged to final year and $(42.5 \%)$ were interns. $(76.9 \%)$ respondents were female.

\section{Desire to Pursue Speciality}

$89.6 \%(n=190)$ respondents desired to pursue a specialisation out of which $91 \%(n=111)$ were final year students and $87.8 \%$ $(n=79)$ were interns. (Table 1)

\section{Speciality Exposure in Their Respective Colleges}

Out of $(n=212)$ respondents, majority $68.4 \%(n=145)$ of them felt that their respective college provided enough encouragement and exposure to pursue specialisations. Of this 72.1 percent were in the final year and 63.3 percent were interns. (Table 2)

\section{Choice of Specialisations}

Out of all the respondents, $93.9 \%(n=199)$ preferred to pursue specialisation in clinical subjects, of which 95.9\% ( $\mathrm{n}=117)$ belonged to final year and $93.9 \%(n=82)$ were interns. Amongst the final year students, Oral surgery was the first choice of specialisation whereas among interns it was Conservative \& Endodontics. Also, the second most popular choice of subject among final years and interns was Orthodontics. In non-clinical subjects the most popular choice for specialisation was Oral Radiology among both the final year students and interns. (Table 3 ). It was also observed that majority of male students $(36.7 \%)$ preferred Orthodontics as their first choice of specialisation whereas female students chose conservative dentistry as their first choice (31.9\%). (Table 4).

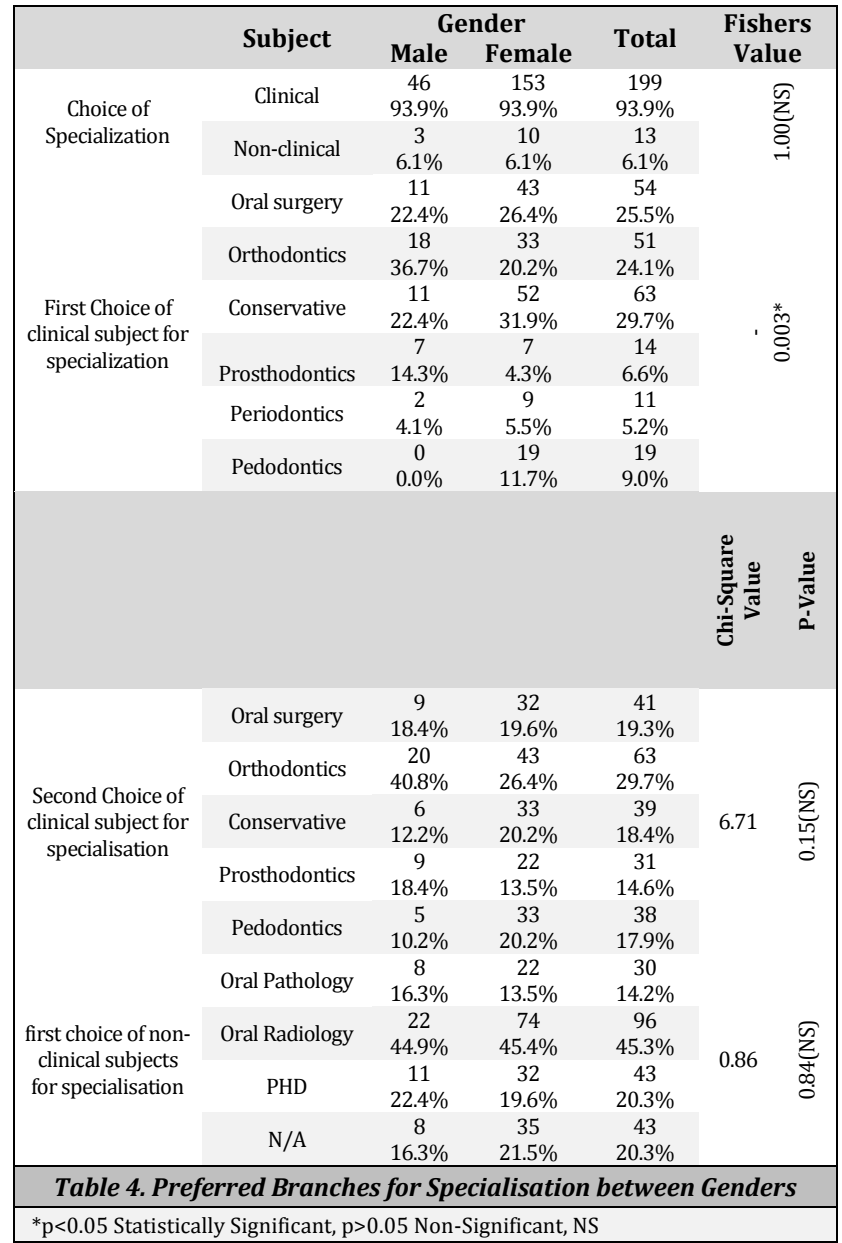

\begin{tabular}{|c|c|c|c|c|c|c|}
\hline & \multirow[t]{2}{*}{ Factors } & \multicolumn{2}{|c|}{ Category } & \multirow[b]{2}{*}{ Total } & \multicolumn{2}{|c|}{ Chi Square Test } \\
\hline & & $\begin{array}{l}\text { Final } \\
\text { Year }\end{array}$ & Intern & & $\begin{array}{l}\text { Chi } \\
\text { Square } \\
\text { Value }\end{array}$ & p-value \\
\hline \multirow{6}{*}{$\begin{array}{l}\text { Factors most } \\
\text { likely to affect } \\
\text { decision on } \\
\text { specialization }\end{array}$} & Family and & 12 & 5 & 17 & \multirow{6}{*}{8.62} & \multirow{6}{*}{$0.04^{*}$} \\
\hline & $\begin{array}{c}\text { friends' } \\
\text { expectations }\end{array}$ & $9.8 \%$ & $5.6 \%$ & $8.0 \%$ & & \\
\hline & $\begin{array}{l}\text { Financial } \\
\text { reasons }\end{array}$ & $\begin{array}{c}30 \\
24.6 \%\end{array}$ & $\begin{array}{c}14 \\
15.6 \%\end{array}$ & $\begin{array}{c}44 \\
20.8 \%\end{array}$ & & \\
\hline & Further & 16 & 6 & 22 & & \\
\hline & studying & $13.1 \%$ & $6.7 \%$ & $10.4 \%$ & & \\
\hline & $\begin{array}{c}\text { Personal } \\
\text { interest }\end{array}$ & $\begin{array}{c}64 \\
52.5 \%\end{array}$ & $\begin{array}{c}65 \\
72.2 \%\end{array}$ & $\begin{array}{c}129 \\
60.8 \%\end{array}$ & & \\
\hline \multirow{5}{*}{$\begin{array}{l}\text { Discouraging } \\
\text { Factors }\end{array}$} & $\begin{array}{l}\text { Too time } \\
\text { consuming }\end{array}$ & $\begin{array}{c}18 \\
14.8 \%\end{array}$ & $\begin{array}{c}16 \\
17.8 \%\end{array}$ & $\begin{array}{c}34 \\
16.0 \%\end{array}$ & \multirow{5}{*}{6.80} & \multirow{5}{*}{$0.08(\mathrm{NS})$} \\
\hline & Too expensive & $\begin{array}{c}64 \\
52.5 \%\end{array}$ & $\begin{array}{c}32 \\
35.6 \%\end{array}$ & $\begin{array}{c}96 \\
45.3 \%\end{array}$ & & \\
\hline & \multirow{3}{*}{$\begin{array}{l}\text { Too competitive } \\
\text { for further } \\
\text { studying } \\
\text { Saturation of } \\
\text { specialist } \\
\end{array}$} & 11 & 15 & 26 & & \\
\hline & & $9.0 \%$ & $16.7 \%$ & $12.3 \%$ & & \\
\hline & & $\begin{array}{c}29 \\
23.8 \% \\
\end{array}$ & $\begin{array}{c}27 \\
30.0 \% \\
\end{array}$ & $\begin{array}{c}56 \\
26.4 \% \\
\end{array}$ & & \\
\hline \multicolumn{7}{|c|}{$\begin{array}{l}\text { Table 5. Factors Affecting the Choice of } \\
\text { Specialisation between Categories }\end{array}$} \\
\hline
\end{tabular}




\section{Factors Influencing Decision to Specialise}

Of the given factors, majority of students in both final year and internship cited their personal interest as a major factor which would affect their decision to specialise. This was followed by financial reasons in both categories. A major deterring factor to pursue specialisation among both interns and final years was that they found it to be expensive to pursue further studies. (Table 5).

\section{Stress as a Factor}

A total of $72.2 \%(n=153)$ respondents felt that pursuing postgraduation was stressful of which $76.7 \%(n=69)$ were interns and $68.9 \%(n=84)$ belonged to final year.

\section{Perception of Different Fields}

The students' responses were sought regarding their perception of fields with best future in terms of personal quality of life, patient's quality of life and financial benefits. Majority of final year students, $33.3 \%(n=38)$ felt Orthodontics was the branch which was the best in terms of personal quality of life whereas $32.6 \%(n=29)$ chose Endodontics. Concerning patient's quality of life, both final years (34.3\%) and interns (41.1\%) chose Endodontics. The specialisation with the best future in terms of financial benefit was found to be Orthodontics by $55.7 \%$ respondents who were in final year and $48.8 \%$ respondents who were interns.

\section{DISCUSSION}

The questionnaire was designed to cover demographic characteristics, speciality preferences, exposure to various specialities and factors that influenced career preferences such as financial background, family background, and peer pressure. Final year and house surgeons were included in the study since they would have enough exposure and knowledge. As a sign of change in the student mentality, $89.6 \%$ students in the present study were inclined towards choosing specialisation in future.

This finding was similar to findings of Ravi $\mathrm{K}$ et al, Khami et al and Gallagher et al.8,11,12 But the trend is different from the results found by Karibe et $\mathrm{al}^{7}$ where only $37 \%$ and $17 \%$ of Swedish and Japanese students preferred specialisation in dentistry respectively. This result was also in contrast from one reported by Aditya $S, 13$ who found a willingness of $35.1 \%$ to pursue post-graduation among dental interns from India. There are also studies conducted where more than half the students were undecided whether to pursue specialisation or not. ${ }^{14}$ Out of a total of 190 students who intended to pursue specialisation, 144 respondents were female, a trend shown in other studies as well. ${ }^{6}$ Decision to pursue specialisation can be affected by multiple factors, one being the exposure and encouragement from their respective colleges. In this case around sixty eight percent respondents felt that they had sufficient exposure and encouragement from their colleges. Previous studies have proved the positive effect of encouragement on students. ${ }^{14}$
In India, clinical subjects in dentistry include six subjects which comprise of oral surgery, orthodontics, conservative and endodontics, prosthodontics, periodontics and pedodontics. Out of this the most popular amongst final year was found to be oral surgery and amongst interns it was found to be conservative dentistry and endodontics. Second most popular choice of subject amongst both interns and final year was orthodontics. This was in concurrence to a study done in the UK. ${ }^{15,14}$ All the clinical subjects are taught in the final year in under-graduation; hence it can be assumed that the approach towards the subject by a college and interaction with the clinical staff could be a decision-making factor for these undergraduate students. In India, oral surgery is a male dominated field with fewer female surgeons practising, in this study majority of female students preferred oral surgery as their first choice of specialisation whereas male students preferred Orthodontics. This was in concurrence with another study conducted by Sharma et al, ${ }^{6}$ Ravi K et al ${ }^{8}$ and Garla BK. ${ }^{5}$ In contrast to this finding, in other study by Karibe $\mathrm{H} \mathrm{et} \mathrm{al}^{2}{ }^{2}$ oral surgery was found to be very unpopular. It can be assumed that some graduates won't prefer oral surgery due to reasons like sight of blood, overnight duties and hectic procedures like handling of trauma cases ${ }^{6}$. Orthodontics as well as endodontics and conservative dentistry were the second most preferred subjects. Aesthetic concern and relief from pain/maintenance of normal function of oral cavity may be the prime reasons behind seeing an orthodontist and endodontist respectively. These branches seem to yield a good financial reward as well. Periodontics was found to be the least popular choice of specialisation. Non-clinical subjects include oral radiology, oral pathology and public health dentistry. Oral radiology was found to be the most popular non -clinical subject for choice of specialisation.

Personal interest in the subject attributing to $60.8 \%$ of the respondents, was found to be the most important factor influencing the choice of speciality, followed by financial reasons $(20.8 \%)$ This finding was in concurrence with that found out by Huda $\mathrm{N}$ et $\mathrm{al}^{16}$ and Chang PY${ }^{17}$ et al in Pakistani and Taiwanese dental students, respectively. Meanwhile $45.3 \%$ respondents felt that expensive post graduate courses were a major deterring factor from choosing to specialise. Students were also evaluated regarding their perception of field with best future in terms of personal quality of life, patient's quality of life and financial benefits. In terms of personal quality of life orthodontics was the most preferred subject and patient's quality of life endodontics was favoured. When it came to financial benefits again orthodontics was preferred. These results were similar to studies conducted at Harvard.

As perception is subjected to change over time, there is a need of longitudinal studies to capture the dynamics and changes in attitudes within the same group of students at different points during their studies. The self-reported nature of the data could have resulted in information bias. Keeping in mind these limitations, further research work needs to be carried out to find out the changing nature of perceptions regarding future specialisations and unidentified factors impact on graduates' career preferences in the field of dentistry. 


\section{CONCLUSIONS}

This study shows that a major number of undergraduates had an intention to specialise, with Restorative Dentistry and Orthodontics being the most popular subjects, although some were still undecided at this stage. Age and parental occupation did not have any influence on intentions to specialise. Reasons behind students' willingness to pursue post-graduation in respective choice of subject was mostly due to their personal interest. A variety of factors appear to inspire dental students to choose a future dental speciality. So, further study is needed with larger sample size and different areas to confirm the trend of change of behaviour regarding future speciality choice and associated factors among dental students with years of study of dentistry.

\section{REFERENCES}

[1] Jain H, Agarwal A. Current scenario and crisis facing dental college graduates in India. J Clin Diag \& Res 2012;6(1):1-4. https://www.jcdr.net/article_fulltext.asp?id=1892

[2] Brand AA, Chikte UME, Thomas CJ. Choosing Dentistry as a career - a profile of entering students (1992) to the University of Sydney, Australia. Australian Dental Journal 1996;41(3):198-205.

[3] Tom K, Dicksit D, Gundavarapu K. Reasons for choosing dentistry as a career - survey of dental students in AIMST University. 2014.

https://www.researchgate.net/publication/275659532_ Reasons_for_choosing_dentistry_as_a_career

[4] Al-Bitar Z, Sonbol H, Al-Omari I. Reasons for choosing dentistry as a career by Arab dental students. European Journal of Dental Education 2008;12(4):247-51.

[5] Garla Bk. Career aspirations and reasons for choosing dentistry as a career - a survey of dental students in Gandhi dental college and hospital, Bhubaneswar. Annals and Essences of Dentistry 2011;3(2):108-10.
[6] Sharma V, Gupta N, Arora V, et al. Factors affecting future speciality choice among dental students in Haryana. Journal of Scientific Dentistry 2017;7(1):12-17.

[7] Karibe H, Kawakami T, Suzuki A, et al. Career choice and attitudes towards dental education amongst dental students in Japan and Sweden. European Journal of Dental Education 2009;13(2):80-6.

[8] Ravi K, Kumar P. Career aspiration and perspective among students pursuing master course in a private dental college, Chennai. IOSR Journal of Dental and Medical Sciences 2014;13(1):56-8.

[9] Cohen R, Coburn D. Motivations for studying dentistry among first-year dental students. Medical Education 1977;11(2):139-50.

[10] Vigild M, Schwarz E. Characteristics and study motivation of Danish dental students in a longitudinal perspective. European Journal of Dental Education 2001;5(3):127-33.

[11] Khami MR, Murtomaa H, Jafarian M, et al. Study motives and career choices of Iranian dental students. Medical Principles and Practice 2008;17(3):221-6.

[12] Gallagher JE, Patel R, Wilson NHF. The emerging dental workforce: long-term career expectations and influences. A quantitative study of final year dental students' views on their long-term career from one London Dental School. BMC Oral Health 2009;9:35.

[13] Aditya S. Motivations and future aspirations of dental interns: a cross-sectional study. J Res in Dent Sci 2013;4(3):114-8.

[14] Puryer J, Kostova V, Kouznetsova A. Final-year dental undergraduate attitudes towards specialisation. Dentistry Journal 2016;4(3):26.

[15] Reeve PE, Watson CJ. An exploration of the attitudes, personality and performance of dental students. Medical Education 1985;19(3):226-37.

[16] Huda N, Yousuf S. Career preference of final year medical students of Ziauddin Medical University. Education for Health: Change in Learning \& Practice 2006;19(3):34553.

[17] Chang PY, Hung CY, Wang KI, et al. Factors influencing medical students' choice of specialty. Journal of the Formosan Medical Association 2006;105(6):489-96. 